Article

\title{
Who Is Marketised in Colour-Blind Sweden? Racial and Ethnic Representation in Swedish Commercials 2008-2017
}

\author{
Sayaka Osanami Törngren ${ }^{1, * \mathbb{C} \text { and Sofia Ulver }}{ }^{2}$ \\ 1 Malmö Institute for Studies of Migration, Diversity and Welfare, Malmö University, 20506 Malmö, Sweden \\ 2 Department of Business Administration, School of Economics and Management, Lund University, \\ 22007 Lund, Sweden; sofia.ulver@fek.lu.se \\ * Correspondence: sayaka.torngren@mau.se
}

Received: 20 August 2020; Accepted: 29 September 2020; Published: 10 October 2020

check for updates

\begin{abstract}
From a social equality representation perspective, advertising should ideally mirror the multicultural composition at the national market, because mass-mediated identity representations may act as cultural resources for those with marginalised identities. To investigate the observance to such an ideal in a context where the ethnic and racial composition of the population saw a rapid change, this article examines 676 Swedish TV commercials in over the period 2008-2017, and analyses the representation of non-White persons of colour (POC). Through this quantitative and qualitative examination, we find that POC are indeed visible in the commercials, but predominantly in the background or playing minor roles. With the, at times, unproportionally high representation of racial and ethnic diversity in Swedish advertising, we find significant tokenism, or in other words, the structurally ineffectual approach common in market-based multiculturalism.
\end{abstract}

Keywords: advertising; persons of colour; representation; Sweden; tokenism

\section{Introduction}

How multicultural is a country through the eyes of the Market? Although marketing is usually criticised for reproducing dominant power structures in society, mass-mediated identity representations at the marketplace may in fact also act as cultural resources for citizens with marginalised identities (Weinberger and Crockett 2018). Therefore, many social science researchers argue that advertising should ideally mirror the socio-cultural composition of a nation and, given accelerated transnationalism, such composition should intersect with categories of race and ethnicity (Tukachinsky et al. 2015; Peruta and Powers 2017). As the marketing field has become increasingly globalised through the presence of the Internet, and consumers around the world are inevitably exposed to different cultures and racial and ethnic groups, multicultural marketing has gained popularity (Sobol et al. 2018; Cui 1997). Even so, at the same time as liberal norms of diversity are hailed, Western mass media in general tend to continuously present images that conform to dominant cultural norms and promote particular categories of people, voices, values and bodies (Edström 2018; Weinberger and Crockett 2018). In this article, we aim to empirically examine this cultural contradiction by investigating a specific national context where the liberal strategy of multiculturalism is practiced at a public policy level, but where the multicultural representations at the marketplace themselves, albeit heavily debated among consumers (Pripp and Öhlander 2008; Hübinette and Räterlinck 2014; Lundberg 2011; Sahlin 2011; Ulver and Laurell 2020), have been underrepresented as the object of academic research; Sweden.

In the US and other countries with a long history of racial diversity (such as South Africa), a lot of attention has been paid to the media's role, including marketing communications, in issues 
of race and ethnicity (Licsandru and Cui 2019). Studies in the US context consistently reveal the under- and mis-representation of racial and ethnic diversity across different media channels (Mastro and Stamps 2018). Davis (2018) points out that an abundance of research on racial representation and multicultural marketing comes from the US and, to a lesser extent, from Europe (Davis 2018). Indeed, in Sweden, as a European example of increasing racial and ethnic diversity, academic researchers have only recently begun to qualitatively problematise the advertising industry's approach to racial and ethnic representation and its impact on political consumer activism (Ulver and Laurell 2020). Therefore, we still know very little about how this representation in such a context actually looks, how it has changed over time, and how it relates to the theorised cultural contradiction of an ance celebrated and unexecuted equality ethos of liberal multiculturalism (Kymlicka 2013). This article addresses this multifaceted gap descriptively and empirically by looking at how persons of colour (POC) are represented, over time, in high-profile commercials on Swedish television. With this aim, we analysed 676 TV commercials developed for the Swedish market that were aired in the period 2008-2017 and examine here the patterns of representation of POC in these commercials over the decade. We chose to analyse TV commercials that sufficiently represent advert exposure to consumers at a national, general level (Barnet 2009) instead of a targeted and digital advertisement such as those in newspapers and on billboards or seen by a geographically or demographically limited number of people. The results show that POCs on one hand are proportionally represented in quantity in Swedish TV commercials, but that the roles they play are minor and tokenised. In the following sections, we will first account for the empirical context of Sweden as an ideal case for research on multicultural marketing, then we will do a brief literature review of previous research on racial and ethnic representation in marketing, proceed to our quantitative and qualitative analyses, and end by discussing our conclusions.

\section{The Swedish Context}

Sweden has historically been a country of emigration and became a country of immigration only after World II. It has experienced rapid changes in the racial and ethnic landscape of the population in the past 50 years, although it is still predominantly a White European country. However, the growth of its non-European population, especially of Middle Easterners, since the 1980s is evident (Migrationsverket 2018). Today, of Sweden's approximately 10 million residents, 19 per cent are first-generation immigrants born outside Sweden and 9 per cent are non-Swedish citizens. Among the 19 per cent who are first-generation immigrants, around 35 per cent are of Asian and Middle Eastern origin - the largest non-White/European group in Sweden. People of African or Latin American origin represent about 10 and 6 per cent, respectively, of the foreign-born population (Statistics Sweden 2018).

Sweden does not register information about individuals' ethnicity and race. Administrative data available to work out the racial and ethnic diversity of the country can be acquired only from a person's country of birth and origin-defined as a 'foreign background'. The population of Sweden with a foreign background (the foreign-born and the native-born with two foreign-born parents) increased from 18 per cent in 2008 to 25 per cent by 2017. The native-born population with two native-born parents—-the so-called 'ethnic Swedes' - decreased from 75 per cent in 2008 to 68 in 2017.

Based on individuals' country of origin and ancestry, the largest ethnic minority identified in Sweden is Finns, who make up approximately 5 per cent of the Swedish population. Other major countries of origin include Syria, Iraq and Iran, which together comprise around 5 per cent of the population. Table 1 shows the foreign-born population in Sweden by country of origin, from which we can infer the racial composition of the country. Persons of Middle Eastern and North African (MENA) background-and especially Middle Eastern background (incorporated within the category 'Asian') - make up the largest foreign-born racial minority in Sweden today (7.3 per cent). Considering the number of newly arriving immigrants in Sweden every year, the MENA group is expected to remain the largest minority in the coming years. From these statistics, we can assume that around 10 per cent of the population in Sweden are of foreign-born POC background. 
Table 1. Country of birth by geographical region (Statistics as of 31 December 2017).

\begin{tabular}{cc}
\hline Region & $\%$ \\
\hline Africa & 2.2 \\
Asia (including the Middle East) & 7.3 \\
EU28 (excluding the Nordic countries) & 3.6 \\
Other Europe (excluding EU28 and the Nordic countries) & 2.6 \\
Nordic countries (excluding Sweden) & 2.0 \\
North America/Oceania & 0.5 \\
Latin America & 0.7 \\
Total & 19.0 \\
\hline
\end{tabular}

Despite the scientific prominence of the idea of a biological race that existed in Sweden in the early 1900s (read more in, e.g., Hagerman 2007; Osanami Törngren 2011), Sweden today is often said to be a racially colour-blind society (Hübinette and Lundström 2014). Race as a concept, category and word is completely abolished at governmental and official levels (Osanami Törngren 2019; Hübinette et al. 2012; Hübinette and Lundström 2014; Hübinette 2017). From that perspective, Sweden represents a post-racial society in which race as a social category is regarded as irrelevant when discussing discrimination, social injustice and inequality because human rights, democracy, gender equality and antiracism are considered already ensured through existing anti-discrimination legislation (Hübinette and Lundström 2014). However, research shows that race does, indeed, matter in different aspects of Swedish society (Osanami Törngren 2020).

These swift turns in history, in combination with current, polarised political tensions about immigration from the Middle East and North Africa-which increased radically in 2015 with the extended Syrian refugee crisis-makes Sweden an aptly relevant case in which to explore changing ethnic/racial diversity relations and roles in market-based representations.

\section{Previous Research}

This article is empirically driven and takes a multidisciplinary approach, focusing on the idea of multicultural marketing. The following review of previous research will address the importance of understanding the practice of representation not just by asking the question whether there is a representation or not, but also how representation is practiced.

\subsection{The Representation of Racial and Ethnic Diversity in Commercials}

According to research in media psychology and intergroup communication, images and messages associated with racial/ethnic groups in the media contribute to the formation, activation and application of racial/ethnic awareness and bias (Mastro 2017; Mastro and Stamps 2018). The media has the potential to promote or to call into question stereotypical views of social groups such as those defined by race and gender; therefore, efforts have been made for education to address the media's role in this issue (Scharrer and Ramasubramanian 2015; Akkestam 2017). Scholars have shown how exposure to mediated out-group members can increase in-group favouritism. Empirical evidences from the US indicates that viewing stereotypical characterisations of racial/ethnic minority groups by White audiences promotes both harmful perceptions of Blacks in society and unfavorable views on diversity-related policy issues such as affirmative action and policing. On the other hand, viewing positive depictions can produce more constructive and sympathetic views about diverse groups as well as more favourable policy (Fujioka 1999; Punyanunt-Carter 2008; Maree and Jordaan 2016). Positive media representations of ethnic minorities can have pro-social effects, fostering positive intergroup attitudes (Tukachinsky et al. 2015; Mastro 2015).

In cultural studies, analyses of the representation of Whiteness and non-Whiteness in Swedish films, literature and news media are fairly prevalent (Brune 1998, 2002, 2004b, 2004a; Gokieli 2017; Karlsson 2014; Khosravi 2009; Tigervall 2005; Tigervall and Hübinette 2010; Hultén 2006; Riegert and Hovden 2019). 
These studies argue that the representation of POC, using the term 'immigrants' in Swedish newspapers and other media outlets, shows certain stereotypes (especially of males and females from MENA regions). However, there are also many stories about experiences of 'success' achieved undeterred by the discriminatory and racist harassment (Riegert and Hovden 2019; Khosravi 2009).

Despite the body of research already conducted on the representation of POC in the Swedish media in general, academia has not focused on racial/ethnic representations in Swedish advertising, neither within the marketing and business fields nor in ethnic studies. While there are studies looking at gender representation (Edström 2018; Åkestam 2018), studies concerning POC representation in Swedish commercials are relatively few (Åkestam 2017; Ulver et al. 2019).

Market-based representation has become a crucial aspect to examine in societies characterised by racial and ethnic diversity because 'images serve to convey meaning and help shape social attitudes towards people and cultures' (Davis 2018, p. 145), and as frequent depictions do not necessarily equate with favourable representation, it is important to consider how racial and ethnic groups are portrayed. For example, in the US context, although quantitatively well represented on prime-time television (Mastro and Stamps 2018), Black depictions continue to embody many stereotypes-such as their being unintelligent, athletic, criminal, aggressive and sexual (Dixon et al. 2019)—and are often presented in a predominantly Black context (Mastro and Stamps 2018). However, there is limited research on the portrayal of Blacks in advertising outside of the US (Davis 2018).

Contrary to Black representation, Asians and Latinx are particularly under-represented relative to their real-life population (Tukachinsky et al. 2015). Studies from the US identify that Asians often appear in background roles but are rarely depicted in major roles in adverts aired on TV (Taylor and Stern 1997) and are thus invisible due to the lack of numerical representation (Chin et al. 2007). What has been repeatedly pointed out over past decades is the stereotypical portrayal of Asian Americans, thus fostering the idea of Model Minorities (Taylor and Stern 1997; Zhang 2010). Paek and Shah (2003) found that Asian Americans are frequently depicted in printed advertising as highly educated, technologically minded and affluent. These findings suggest that, over the years, Asians have been positively represented as long as 'they stayed "in their place"' (Davis 2018, p. 152).

Middle Easterners are rarely addressed in the US context, even though they are racialised (Davis 2018; Mastro 2017). Studies on media representation in general show that Middle Easterners are often portrayed in a negative way connected to migration, and to Islam, which is seen as a violent religion (Ahmed and Matthes 2017; Khosravi 2009; Mukhtar-Landgren 2008).

This article specifically focuses on a single categorical POC representation in Swedish TV commercials; however, the authors are aware of the range of intersectional effects of representation. For example, studies show that women are significantly under-employed as lead presenters (Peruta and Powers 2017; Fowler and Thomas 2015; Martinez et al. 2012) and that race, gender and age form an intersectional marginalisation in representation in advertisements (Gopaldas and Siebert 2018; Persaud et al. 2018).

\subsection{Multicultural Marketing and Tokenism}

In the 1980s, scholars' interest in the consumption patterns of ethnic and racial minorities and in strategies in targeted marketing has increased due to the globalising market. Race and ethnicity play an ideological role in the market place and are 'a key site of hierarchy' (Grier et al. 2019). Different marketing strategies have developed to cater to consumers, including 'ethnic marketing' - the targeting of a specific ethnic market-and 'multicultural marketing', where brand communication is directed at specific or overlapping ethnic consumer groups in culturally and ethnically diverse societies. Within the managerial marketing literature, researchers have first and foremost concentrated on which minority groups possess the highest buying power and through which channels these can best be targeted (Precourt 2014; Makgosa 2012; Cui 1997; Johnson and Grier 2011) as well as the ways in which these groups have become increasingly difficult to define demographically over recent decades (Korzenny 2008). 
Consumer culture researcher Peñaloza (2018) calls for a redefinition of 'ethnic marketing', which traditionally focused on non-White ethnic consumers. She calls attention to the need for plural connotations of the terms 'ethnicity' and 'ethnic marketing' which would benefit both minority and majority ethnic consumers alike and society at large (Peñaloza 2018). This flexibility in understanding ethnicity and ethnic marketing is important, as the multiple generations of ethnic minorities and majorities engage with their cultural heritage both symbolically and optionally (Gans 1979; Waters 1990; Song 2003).

In line with such flexibility, but on a policy level, Sweden has incorporated a liberal multicultural policy aimed to respect cultural differences and individual rights (Fernández 2019; Borevi 2014; Schierup and Ålund 2011). Liberal multiculturalism 'seeks to integrate different cultural groups into a universal citizenship and tolerates particularistic cultural practices in private' and, as a consequence, is reflected in a limited adoption of multicultural marketing strategies (Burton 2002). For example, Horsti and Hultén (2011), comparing Finnish and Swedish Public Service Broadcasters, conclude that, in Sweden, multicultural policies are replaced by integrationist polices; this creates mainstream cultural diversity instead of aiming to provide specific services for minority groups. This 'serve all' public service programming is also believed to be economically beneficial too (Horsti and Hultén 2011).

Here, tokenism becomes an important concept in understanding the portrayal of racial and ethnic diversity in the media. Tokenism is

... the practice or policy of admitting an extremely small number of members of racial (e.g., African American), ethnic (e.g., Latino) or gender (i.e., women) groups to work, educational, or social activities to give the impression of being inclusive, when in actuality these groups are not welcomed. In the workplace the practice has been relied on to show compliance with laws, rules, and regulations requiring institutions to hire people of color or women. (Riccucci 2008, p. 132)

The concept has developed in a US context where there was, initially, a systemic exclusion of African Americans; this was followed by the Civil Rights movement and the opening up of opportunities for African Americans to participate in different aspects of society through quotas, in small numbers. Tokenism flourishes in an environment where diversity is created through only allowing a few minorities to enter the space, while discriminatory practice is maintained (Riccucci 2008). While tokenism is believed to open doors for minorities, research shows how the practice is demeaning and undermines people's identity (Niemann 1999; Jackson et al. 1995). Those who are the subject of tokenism are always reminded of their differences and that they must present themselves in particular ways to be worthy of success. The differences that tokenism presents must be significant enough from the dominant norms while, at the same time, be recognised as having similar enough values and/or characteristics to the dominant culture; tokenism is constrained by the expectation of the dominant culture (Gent 2017). Marketers, for example, use Blackness—such as Black culture, speech, style, fashion and music—to sell products (Davis 2018), which calls into question the representation of Blacks as tokenism (Riccucci 2008). Moreover, even though Black portrayal has bettered significantly since the 1980s in the US, the Black character's isolation still raises questions regarding the persistence of stereotypical representation and tokenism (Mastro and Stamps 2018; Crockett 2008). Swedish scholars analysing Swedish films argue that racial and ethnic minorities are more often portrayed in a sympathetic manner with a focus on their 'differences' (Karlsson 2014; Tigervall 2005; Pallas 2011). These studies infer how minorities might be tokenised.

\section{Data and Method}

Taking into account that much advertising today is digital and carefully targeted, we needed to identify commercials that should sufficiently represent ad exposure to consumers at a national, general level and let alone seen by a majority (Barnet 2009). Therefore, we focused on analysing TV commercials for this study. The data collection was conducted by four research assistants instructed 
and trained by a post doc researcher and the second author. The data consist of $676 \mathrm{TV}$ commercials by the 11 largest advert buyer brands during the period 2008-2017 identified through a selection process and checking specifically for the use of TV commercials from Sifo's Reklammätningar list (Frick 2019). Advertising agencies were contacted and asked if they wanted to participate in the study by sending YouTube links or actual film files of all the commercials they had created and launched for each brand.

We are aware of the bias that might exist in the selection of 676 commercials. As seen in Table 2, the number of commercials analysed for each brand and product category varies significantly, with an oversampling of ICA (grocery retailer) commercials. ICA is by far the largest ad buyer, having a series of commercials in a sitcom style, sending a new commercial episode once a week, which amounts to a total of 520 films during the period. Even though there is an imbalance in the number of commercials per brand, we do not observe any statistically significant correlation between them (comparing ICA and other brands) and the representation of non-Whites $(r=0.138)$.

Table 2. Number of commercials analysed per brand $(\mathrm{N}=676)$.

\begin{tabular}{cc}
\hline Brand & TOTAL \\
\hline ICA (Grocery) & 355 \\
Coop (Grocery) & 47 \\
El-Giganten (Home electronics) & 4 \\
Telia (Telecom) & 37 \\
Tre (Telecom) & 24 \\
Tele2 (Telecom) & 20 \\
Volkswagen (Automobiles) & 11 \\
Telenor (Telecom) & 70 \\
IKEA (Home electronics) & 72 \\
McD (Fastfood) & 15 \\
Volvo (Automobiles) & 21 \\
\hline
\end{tabular}

The content of the selected 676 commercials was coded according to a checklist. To find the frequency of POC representation in the commercial, we applied Taylor and Stern (1997) analytical frame of "White"/"Non-White" actors (The viewers were given the following instructions in distinguishing White/non-White actors: 'Identify the persons with non-White skin colour. This can be based on their ethnicity or origin such as Asian, African, African American, Sami, Arabic, MENA, native American. You should not give the specific racial background of the person but simply count the numbers. If you are unsure of the categories, leave the number marked in red so that the involved researcher can double check'). It is important to note that the coding, since the researchers did not have access to the self-identified racial and ethnic identification of the actors, or the manuscript of the content of the commercials, is all based on the external assignment of observed race and ethnicity (Roth 2016). The data collection focused on the POC representation in commercials and therefore gender was not coded.

The first type of coding was the counting of numbers, for example, the number of White/non-White people in the commercials and how many types of role they played. The second type of coding was more subjective- the student assistants were asked to take a binary stance of Yes or No to questions such as whether there were interactions between White and non-White people or whether the viewer perceived the commercial to be taking place in a multicultural setting (Instruction for this subjective coding said: 'White and non-White actors interact with each other through, for example, talking, working together or hanging out', as well as 'Do you perceive this commercial to show a multicultural context?'). Such a coding, which involves a subjective assessment of commercials, is a valuable indication of how the latter are perceived by the viewers. Each commercial was coded by two different researchers, blind to each other's coding. The coding was then examined for disagreements by a third coder (the authors of this article). Where disagreements were found, the third coder watched the commercial to reach a conclusion. 
The study utilises a mixed-method approach which allows for an analysis of the quantity and quality of POC representation. First, we conducted a quantitative analysis examining the mere frequency of representation of non-White (relative to White) actors in Swedish advertising and the roles that POC plays (Taylor and Stern 1997). Using SPSS, descriptive statistics and some correlations (through Pearson's correlation) between different aspects of the commercials are generated.

Simultaneously, we conducted a more qualitative analysis examining the roles and qualities of the non-White actors in line with the quantitative coding scheme. Commercials with the largest number of POC represented, playing leading and speaking roles, are analysed qualitatively. As the quantitative coding only gave information on whether the actors appearing in the commercials were White or non-White, we focused on the specific racial and ethnic representation of POC in commercials, the list of which can be found in Appendix A.

\section{Analysis}

\subsection{Quantitative Analysis}

\subsubsection{Descriptive Analysis}

Among the 676 commercials analysed in this article, 26 per cent $(\mathrm{N}=176)$ had at least one POC in them while five portrayed no White actors. With an assumption we made earlier that around 10 per cent of the foreign-born population in Sweden are POC, together with the information that, in 2017, 25 per cent of the total population had at least one foreign-born parent, a total non-White representation of 26 per cent is a promising number.

The representation of POC varies over the years, with a spike of representation in 2016, when 51 per cent of the commercials analysed contained at least one non-White actor. Moreover, there seems to be an increase in, and even an over-representation of, non-White actors playing background roles over the years. At the same time, we can argue that there is an under-representation of White actors playing background roles, with some years seeing the percentage drop to below 50 per cent. When a White character is present in a commercial, the actor almost always plays the main or speaking role (80-98 per cent) — not the case for non-White actors. Among the total of 176 commercials with non-White representation, only 38 commercials (22\%) had the POC playing the main role. Among those 38 commercials, 25 commercials had the actors in a speaking role. Even in 2016, with 51 per cent of the commercials representing non-White actors, only 14 per cent had a POC as a main character, with 22.5 per cent having a speaking role. (see Table 3)

Table 3. Non-White representation per year (\%).

\begin{tabular}{cccccc}
\hline \multirow{2}{*}{ Year } & \multirow{2}{*}{ Total } & \multicolumn{4}{c}{ Roles } \\
\cline { 3 - 6 } & & Main & Speaking & Minor & Background \\
\hline $2008(\mathrm{~N}=32)$ & 25.0 & 15.6 & 9.4 & 3.1 & 6.3 \\
$2009(\mathrm{~N}=39)$ & 10.3 & 0.0 & 5.1 & 5.1 & 5.1 \\
$2010(\mathrm{~N}=51)$ & 13.7 & 3.9 & 5.9 & 7.8 & 2.0 \\
$2011(\mathrm{~N}=59)$ & 10.2 & 0.0 & 0.0 & 1.7 & 8.5 \\
$2012(\mathrm{~N}=112)$ & 23.5 & 3.5 & 3.5 & 10.4 & 15.7 \\
$2013(\mathrm{~N}=63)$ & 14.3 & 4.8 & 7.9 & 3.2 & 1.6 \\
$2014(\mathrm{~N}=74)$ & 29.7 & 4.1 & 6.8 & 1.4 & 17.6 \\
$2015(\mathrm{~N}=70)$ & 27.1 & 7.1 & 8.6 & 8.6 & 15.7 \\
$2016(\mathrm{~N}=80)$ & 53.1 & 13.8 & 22.5 & 16.3 & 20.0 \\
$2017(\mathrm{~N}=93)$ & 35.5 & 5.4 & 6.5 & 9.7 & 25.8 \\
TOTAL & 26.0 & 5.6 & 7.7 & 7.5 & 13.8 \\
\hline
\end{tabular}


Analysing the relationship portrayed in the commercials through a breakdown of White and non-White actors, the White representation mirrors the total proportion of each relationship category that the commercials portray, while POC do exhibit a slightly deviating pattern. What we can observe here (see Table 4) is the unproportionally high percentage of representation of POC in a combination of two or more of the relationships (22.9 per cent in total, 38 per cent for non-Whites). This means that POC might to be representing no specific relationship but functioning in the commercial as background characters, for example.

Table 4. Relationships portrayed (\%).

\begin{tabular}{cccc}
\hline Relations & $\begin{array}{c}\text { Non-White } \\
\mathbf{( N = \mathbf { 1 7 6 } )}\end{array}$ & $\begin{array}{c}\text { White } \\
\mathbf{( N = 6 7 1 )}\end{array}$ & $\begin{array}{c}\text { TOTAL } \\
\mathbf{( N = 6 7 6 )}\end{array}$ \\
\hline No interaction & 9.1 & 12.5 & 12.7 \\
Family & 15.9 & 17.6 & 17.5 \\
Friends & 4.5 & 6.6 & 6.5 \\
Work & 26.1 & 34.7 & 34.8 \\
Other & 6.3 & 5.5 & 5.6 \\
Combination of two or more of the above & 38.1 & 23.1 & 22.9 \\
\hline
\end{tabular}

Analysing representation in different product categories, the White actors are used equally across the different product categories, while the non-White actors are proportionally more apparent in Telecom (22.3 per cent total, 26.1 for non-Whites) and Automobile (4.7 per cent total, 7.4 for non-Whites) commercials. This is interesting in terms of previous studies in the US which showed an under-representation of racial minorities in technology advertising while specific racial groups such as East Asians were embedded into 'upper-class' stereotypes connected to economic success (Persaud et al. 2018; Taylor and Stern 1997; Paek and Shah 2003; Crockett 2008).

Of the 671 commercials that use White actors, 91 per cent have one or more White actors playing the main character, while only 22 per cent of 176 commercials portray non-White actors as the main character (see Table 5). It is clear that POC are playing both main and speaking roles and even minor roles in the analysed commercials to a proportionally lesser extent than White actors.

Table 5. Roles divided by White/non-White representation (\%).

\begin{tabular}{ccccc}
\hline & \multicolumn{4}{c}{ Roles } \\
\cline { 2 - 5 } & Main & Speaking & Minor & Background \\
\hline White $(\mathrm{N}=671)$ & 91.1 & 77.3 & 56.3 & 53.7 \\
Non-White $(\mathrm{N}=176)$ & 21.6 & 29.5 & 29.0 & 52.8 \\
\hline
\end{tabular}

A total of 18.5 per cent of commercials show an interaction between White and non-White actors. Looking at this percentage, we observe a noteworthy increase-from 6.3 per cent in 2008 to 20.4 in 2017, peaking in 2016 at 45 per cent. In 82 per cent of the 176 commercials in which non-White actors are used, the non-White and White actors interact. Even though the proportion of commercials that show interaction between White and non-White actors has increased, only 13.6 per cent $(N=92)$ out of 676 commercials were rated as portraying a multicultural setting, 73 per cent of which were rated as representing multiculturalism in Sweden in a positive way.

\subsubsection{The Correlation between Different Variables}

We look at the correlation between different variables through Pearson's correlation. We run two analysis: Firstly, we look at the correlations comparing the two periods (2008-2012/2013-2017 binary) and the representation of POC in different roles (representation/no representation binary). Secondly, we look at the correlations between the years and the number of POC (continuous variable) represented. Through these two analyses, we look at whether POC are represented or not in 
commercials over the years and whether there is an increase or decrease in the number of POC represented throughout the years we analyse.

As can be seen in Table 6, we observe correlation between the years and POC representation $(\mathrm{r}=0.170)$; however, the correlation only explains $2 \%$ of the variance and we can conclude that the two periods (2008-2012 and 2013-2017) have no significant effects in the representation of non-White actors in the Swedish commercials that are analysed. We observe correlation between years and representation of POC in speaking roles, background roles and White/non-White interactions; however, the correlations are not statistically significant (explaining less than $2 \%$ of variances). What we see, which is not surprising, is the positive correlations between non-White representation and the different roles that the actors play. In particular, the correlation is moderate to strong for non-Whites playing background roles $(r=0.654)$, White/non-White roles interacting $(r=0.717)$ and the perception of commercials portraying multicultural contexts $(r=0.639)$. These correlations explain 43,51 and 41 per cent of the variation, respectively. There is also a moderate correlation between the perception of the commercials as portraying a multicultural context and non-White actors playing a background role $(r=0.591)$, which explains 35 per cent of the variations. This observation is especially interesting since, even though there were only two raters for each commercial, having non-White actors in the background does initiate the perception that the commercial is taking place in a multicultural context. Here, we can argue that non-White actors in the background do play a token role, representing the racial and ethnic diversity of Sweden. Moreover, the correlation seen for non-Whites playing a background role should be noted, especially because non-Whites in the main role or speaking roles do not show any statistically significant correlation. This strengthens our argument that non-White actors are used as tokens in the 676 commercials selected for the analysis.

We have established that we do not see a correlation between the two periods we compare (2008-2012 and 2013-2017) and the representation of POC. Table 7 specifically looks at the correlation between the two periods and the number of POC (continuous variable) represented. Here again, there is no statistically significant correlation between two periods and the number of non-White actors represented, where only $1.7 \%$ of the variances can be explained $(r=0.132)$. Other variables that show correlations are also not statistically significant enough. The only statistically significant moderate correlation observed is the number of non-White actors represented in the commercials and of the non-Whites playing minor roles $(r=0.657)$, background roles $(r=0.578)$, White/non-White interaction $(r=0.578)$ and the perception of the commercials portraying multicultural settings $(r=0.605)$. These positive correlations explain between 33 and 43 per cent of the variance. The correlation is the highest for the number of non-White actors playing minor roles. This clearly shows that, when the number of POC increases in a commercial, they tend to be utilised not in main or speaking roles but, rather, are limited to appearing in minor roles. Even though POC play minor roles, their representation in quantity gives an impression that the advertisement depicts a multicultural context, which suggest POC's role as tokens of diversity. 
Table 6. Correlation between year and non-White representation.

\begin{tabular}{|c|c|c|c|c|c|c|c|c|c|}
\hline \multicolumn{10}{|c|}{ Correlations } \\
\hline & & Year & $\begin{array}{c}\text { Non-White } \\
\text { Representation }\end{array}$ & $\begin{array}{l}\text { Non-White } \\
\text { Main }\end{array}$ & $\begin{array}{l}\text { Non-White } \\
\text { Speaking }\end{array}$ & $\begin{array}{l}\text { Non-White } \\
\text { Minor }\end{array}$ & $\begin{array}{c}\text { Non-White } \\
\text { Background Role }\end{array}$ & $\begin{array}{l}\text { White/Non-White } \\
\text { Interact }\end{array}$ & $\begin{array}{c}\text { Multicultural } \\
\text { Context }\end{array}$ \\
\hline \multirow{3}{*}{ Year } & Pearson Correlation & 1 & 0.170 ** & 0.073 & $0.121 * *$ & 0.026 & $0.110 * *$ & $0.156^{* *}$ & 0.055 \\
\hline & Sig. (2tailed) & & 0.000 & 0.058 & 0.002 & 0.494 & 0.004 & 0.000 & 0.156 \\
\hline & $\mathrm{N}$ & 676 & 676 & 676 & 676 & 676 & 676 & 676 & 676 \\
\hline \multirow{3}{*}{$\begin{array}{l}\text { Non-white } \\
\text { representation }\end{array}$} & Pearson Correlation & $0.170 * *$ & 1 & $0.411^{* *}$ & $0.487^{* *}$ & $0.481^{* *}$ & $0.654^{* *}$ & $0.717^{* *}$ & $0.639 *$ \\
\hline & Sig. (2tailed) & 0.000 & 0.000 & 0.000 & 0.000 & 0.000 & 0.000 & 0.000 & 0.000 \\
\hline & $\mathrm{N}$ & 676 & 676 & 676 & 676 & 676 & 676 & 676 & 676 \\
\hline \multirow{2}{*}{$\begin{array}{l}\text { Non-white } \\
\text { main }\end{array}$} & Sig. (2tailed) & 0.058 & 0.000 & & 0.000 & 0.000 & 0.005 & 0.000 & 0.000 \\
\hline & $\mathrm{N}$ & 676 & 676 & 676 & 676 & 676 & 676 & 676 & 676 \\
\hline \multirow{3}{*}{$\begin{array}{l}\text { Non-white } \\
\text { speaking }\end{array}$} & Pearson Correlation & 0.121 ** & $0.487^{* *}$ & $0.532 * *$ & 1 & $0.359 * *$ & $0.094^{*}$ & $0.390 * *$ & $0.387 *$ \\
\hline & Sig. (2tailed) & 0.002 & 0.000 & 0.000 & & 0.000 & 0.014 & 0.000 & 0.000 \\
\hline & $\mathrm{N}$ & 676 & 676 & 676 & 676 & 676 & 676 & 676 & 676 \\
\hline \multirow{3}{*}{$\begin{array}{l}\text { Non-white } \\
\text { minor }\end{array}$} & Pearson Correlation & 0.026 & $0.481^{* *}$ & $0.173 * *$ & $0.359 * *$ & 1 & $0.244^{* *}$ & $0.437^{* *}$ & $0.377^{*}$ \\
\hline & Sig. (2tailed) & 0.494 & 0.000 & 0.000 & 0.000 & & 0.000 & 0.000 & 0.000 \\
\hline & $\mathrm{N}$ & 676 & 676 & 676 & 676 & 676 & 676 & 676 & 676 \\
\hline \multirow{2}{*}{$\begin{array}{l}\text { Non-white } \\
\text { background } \\
\text { role }\end{array}$} & Pearson Correlation & $0.110^{* *}$ & $0.654^{* *}$ & $0.108^{* *}$ & $0.094 *$ & $0.244^{* *}$ & 1 & $0.419^{* *}$ & $0.393^{* *}$ \\
\hline & $\mathrm{N}$ & 676 & 676 & 676 & 676 & 676 & 676 & 676 & 676 \\
\hline \multirow{3}{*}{$\begin{array}{l}\text { White/nonwhite } \\
\text { interact }\end{array}$} & Pearson Correlation & $0.156^{* *}$ & $0.717^{* *}$ & $0.264^{* *}$ & 0.390 ** & $0.437^{* *}$ & 0.419 ** & 1 & $0.591^{* *}$ \\
\hline & Sig. (2tailed) & 0.000 & 0.000 & 0.000 & 0.000 & 0.000 & 0.000 & & 0.000 \\
\hline & $\mathrm{N}$ & 676 & 676 & 676 & 676 & 676 & 676 & 676 & 676 \\
\hline \multirow{3}{*}{$\begin{array}{l}\text { Multicultural } \\
\text { context }\end{array}$} & Pearson Correlation & 0.055 & $0.639^{* *}$ & $0.446^{* *}$ & $0.387^{* *}$ & $0.377^{* *}$ & 0.393 ** & 0.591 ** & 1 \\
\hline & Sig. (2tailed) & 0.156 & 0.000 & 0.000 & 0.000 & 0.000 & 0.000 & 0.000 & \\
\hline & $\mathrm{N}$ & 676 & 676 & 676 & 676 & 676 & 676 & 676 & 676 \\
\hline
\end{tabular}

** Correlation is significant at the 0.01 level (2-tailed). ${ }^{*}$ Correlation is significant at the 0.05 level (2-tailed). Cannot be computed because at least one of the variables is constant. 
Table 7. Correlation between year and the number of non-White actors in the commercials.

\begin{tabular}{|c|c|c|c|c|c|c|c|c|c|}
\hline \multicolumn{10}{|c|}{ Correlations } \\
\hline & & Year & $\begin{array}{c}\text { Non-White } \\
\text { Representation }\end{array}$ & $\begin{array}{l}\text { Non-White } \\
\text { Main }\end{array}$ & $\begin{array}{l}\text { Non-White } \\
\text { Speaking }\end{array}$ & $\begin{array}{l}\text { Non-White } \\
\text { Minor }\end{array}$ & $\begin{array}{c}\text { Non-White } \\
\text { Background Role }\end{array}$ & $\begin{array}{l}\text { White/Non-White } \\
\text { Interact }\end{array}$ & $\begin{array}{c}\text { Multicultural } \\
\text { Context }\end{array}$ \\
\hline \multirow{3}{*}{ Year } & Pearson Correlation & 1 & $0.132 * *$ & 0.069 & $0.104^{* *}$ & $0.077^{*}$ & 0.058 & $0.156^{* *}$ & 0.055 \\
\hline & Sig. (2tailed) & & 0.001 & 0.074 & 0.007 & 0.046 & 0.131 & 0.000 & 0.156 \\
\hline & $\mathrm{N}$ & 676 & 676 & 676 & 676 & 676 & 676 & 676 & 676 \\
\hline \multirow{3}{*}{$\begin{array}{l}\text { Non-white } \\
\text { representation }\end{array}$} & Pearson Correlation & $0.132 * *$ & 1 & $0.411 * *$ & $0.400^{* *}$ & $0.657^{* *}$ & $0.578^{* *}$ & $0.587^{* *}$ & $0.605^{* *}$ \\
\hline & Sig. (2tailed) & 0.001 & & 0.000 & 0.000 & 0.000 & 0.000 & 0.000 & 0.000 \\
\hline & $\mathrm{N}$ & 676 & 676 & 676 & 676 & 676 & 676 & 676 & 676 \\
\hline \multirow{2}{*}{$\begin{array}{l}\text { Non-white } \\
\text { main }\end{array}$} & Sig. (2tailed) & 0.074 & 0.000 & & 0.000 & 0.000 & 0.000 & 0.000 & 0.000 \\
\hline & $\mathrm{N}$ & 676 & 676 & 676 & 676 & 676 & 676 & 676 & 676 \\
\hline \multirow{3}{*}{$\begin{array}{l}\text { Non-white } \\
\text { speaking }\end{array}$} & Pearson Correlation & $0.104^{* *}$ & 0.400 ** & $0.657^{* *}$ & 1 & $0.267^{* *}$ & $0.174^{* *}$ & $0.365^{* *}$ & $0.424 * *$ \\
\hline & Sig. (2tailed) & 0.007 & 0.000 & 0.000 & & 0.000 & 0.000 & 0.000 & 0.000 \\
\hline & $\mathrm{N}$ & 676 & 676 & 676 & 676 & 676 & 676 & 676 & 676 \\
\hline \multirow{3}{*}{$\begin{array}{l}\text { Non-white } \\
\text { minor }\end{array}$} & Pearson Correlation & $0.077^{* *}$ & $0.657^{* *}$ & $0.190 * *$ & $0.267^{* *}$ & 1 & $0.138^{* *}$ & $0.373^{* *}$ & $0.361 * *$ \\
\hline & Sig. (2tailed) & 0.046 & 0.000 & 0.000 & 0.000 & & 0.000 & 0.000 & 0.000 \\
\hline & $\mathrm{N}$ & 676 & 676 & 676 & 676 & 676 & 676 & 676 & 676 \\
\hline $\begin{array}{l}\text { Non-white } \\
\text { background } \\
\text { role }\end{array}$ & $\mathrm{N}$ & 676 & 676 & 676 & 676 & 676 & 676 & 676 & 676 \\
\hline \multirow{3}{*}{$\begin{array}{l}\text { White/nonwhite } \\
\text { interact }\end{array}$} & Pearson Correlation & $0.156^{* *}$ & $0.587^{* *}$ & $0.250 * *$ & $0.365^{* *}$ & $0.373^{* *}$ & $0.374^{* *}$ & 1 & $0.591 * *$ \\
\hline & Sig. (2tailed) & 0.000 & 0.000 & 0.000 & 0.000 & 0.000 & 0.000 & & 0.000 \\
\hline & $\mathrm{N}$ & 676 & 676 & 676 & 676 & 676 & 676 & 676 & 676 \\
\hline \multirow{3}{*}{$\begin{array}{l}\text { Multicultural } \\
\text { context }\end{array}$} & Pearson Correlation & 0.055 & $0.605^{* *}$ & 0.460 ** & $0.424^{* *}$ & $0.361 * *$ & $0.400 * *$ & $0.591^{* *}$ & 1 \\
\hline & Sig. (2tailed) & 0.156 & 0.000 & 0.000 & 0.000 & 0.000 & 0.000 & 0.000 & \\
\hline & $\mathrm{N}$ & 676 & 676 & 676 & 676 & 676 & 676 & 676 & 676 \\
\hline
\end{tabular}

** Correlation is significant at the 0.01 level (2-tailed). ${ }^{*}$ Correlation is significant at the 0.05 level (2-tailed). Cannot be computed because at least one of the variables is constant. 


\subsection{Qualitative Analysis}

The qualitative analysis is conducted on the 10 commercials that portray the highest number of POC in three categories: the total number, those playing a main character, and those with a speaking role. Only 23 commercials were qualitatively analysed, due to the overlap of commercials in the three categories; moreover, not all brands are represented in this list. An overview of the commercials analysed can be found in Appendix A. The focus in the qualitative analysis was the largest POC groups in Sweden-namely Asian, Black or Middle-Eastern. Table 8 shows the commercials analysed and which groups are represented. In the majority of the 23 commercials analysed, non-White and White actors interact and some of their relationships are intimate. For example, three White female and Black male interracial couples and two ethnically ambiguous female and White male interracial couples were represented in four different commercials.

Table 8. Representation of racial groups.

\begin{tabular}{|c|c|c|c|c|}
\hline & Black & Asian & Middle-Eastern & Ethnically Ambiguous \\
\hline McDonald's 1 & $x$ & & & \\
\hline McDonald's 2 & $x$ & & & $x$ \\
\hline McDonald's 3 & $x$ & $x$ & & $x$ \\
\hline Volvo 1 & $x$ & $x$ & & $x$ \\
\hline Volvo 2 & $x$ & $x$ & $x$ & $x$ \\
\hline Volvo 3 & $x$ & & & $x$ \\
\hline Tre 1 & $x$ & & & \\
\hline Tre 2 & $x$ & $x$ & & $x$ \\
\hline Tre 3 & $x$ & $x$ & & $x$ \\
\hline Tre 4 & $x$ & & & $x$ \\
\hline ICA 1 & & & $x$ & $x$ \\
\hline ICA 2 & & & $x$ & \\
\hline ICA 3 & & & & $x$ \\
\hline ICA 4 & $x$ & & & $x$ \\
\hline ICA 5 & & $x$ & & \\
\hline Coop 1 & $x$ & & & \\
\hline Coop 2 & $x$ & & & $x$ \\
\hline Volvo 4 & & & & $x$ \\
\hline IKEA & $X$ & & & $x$ \\
\hline Telia 1 & $x$ & $x$ & & $x$ \\
\hline Telenor 1 & $x$ & & & $x$ \\
\hline Telenor 2 & $x$ & & $x$ & $x$ \\
\hline Telenor 3 & & & & $x$ \\
\hline
\end{tabular}

\subsubsection{The Representation of Middle Eastern Actors}

Middle Easterners are racialised based on their presumed religious affiliation and visible phenotypes in Sweden (Khosravi 2009). However, their visibility is sometimes ethnically ambiguous, unless such religious symbols are incorporated. Among the qualitatively analysed commercials, we observed three specific ones in which the female actors, both children and adult, were wearing a headscarf, indicating a religious and Middle Eastern background.

Actors with an ascribed Middle Eastern background interact with the White majority population. Examples are the marriage scene in the McDonald's commercials (2) in which the bride is the non-White figure, presumably Middle Eastern, and the groom is White; the background actors are predominantly of Middle Eastern phenotype. In the Volvo commercials (2), a Middle-Eastern-looking man is working side by side and having a conversation with a White female colleague. However, the Middle Eastern representations are also isolated from the Swedish context and society, one example being the mother (the wife of the previously mentioned man in the Volvo commercial) wearing a headscarf and preparing the child, whom we do not see in the rest of the commercial, for leaving home (2). Two of the commercials with specific reference to the Middle East are contextualised outside of Sweden, as in 
the case of the girl with a headscarf in the Telenor commercials (3) or the Turkish couple in Turkey mocking Swedes (ICA 2).

\subsubsection{The Representation of Black Actors}

Analysing 23 commercials qualitatively, we can conclude that there is a documented quantity of Black actors in Swedish commercials. What becomes interesting is the quality of these Black actors. Black actors interact and share the same space with White actors. There are very few commercials in which a Black person is contextualised outside of Sweden (3). The interactions between Black actors and White actors are as close colleagues (Volvo 2), friends (IKEA) or in intimate relationships (McD 1, McD 2, Tre 1). In several of these films, more than one Black actor is present, and therefore they are not represented in isolation. Four interracial couples in the commercials all portray the male partner as Black and the female partner as White. This is interesting since mixed marriages are more common for White Swedish men and the majority in Sweden are interethnic rather than interracial (Osanami Törngren and Irastorza). The Black actors are also, on several occasions, represented in an equitable manner with the White actors, such as when Black actors play an upper-class person, perhaps dining in an exclusive restaurant, visiting an art gallery or going to a museum (McD 2), or Black consumers in a grocery store (Coop, ICA). Even though the analysis is only based on 23 selected commercials, this result does not correspond to the findings from the US.

The Coop's commercial (1) stands out as it utilises two Black male actors, both of whom have speaking roles. They are the only non-White representation in the commercial, which introduces the Coop and the history of the Swedish food industry. In the beginning, a White woman and man introduce the context - the beginning of the 1900s. The year 1946 is then introduced by a White man, 1963 by a White woman, and 1979 by a Black man with broken Swedish. The commercial then moves on to a White woman introducing 1986 and 2020, with a Coop store today depicted by a Black man speaking in flawless Swedish, and a White woman closing the advertisement. The two Black actors depict the continuity of the Black Swedish existence but also tokenise and symbolise the integration process of the 'successful' Black Swede, particularly because of the timeline and the fluency of their Swedish language.

\subsubsection{The Representation of Asian Actors}

While it became clear that there is a somewhat equitable representation of Black actors in the commercials, Asians-especially East Asians—on the contrary are hardly represented. Half of them portray South Asians and the rest East Asians. While the South Asians are often put into the Swedish context, two out of the four commercials with East Asian actors (ICA 5, Volvo 3) are played outside of the Swedish context. Interestingly these two commercials portray a female East Asian figure (a girl in Volvo and a female in ICA), while the East Asian portrayal in Sweden only shows male figures. Even though the analysis is limited to the 23 commercials, this contradicts with studies in the US indicating that Asian men are less represented in relation to Asian women (Schug et al. 2017).

What is also interesting about the Asian portrayal is that there is no interaction with the majority of White actors. The McDonalds commercial is the only one in which an East Asian male actor talks to and tries to interact with a White female actor (McD 3). The East Asian male actor speaks fluent Swedish; however, this conversation is one way, as the White female actor does not even respond. Another non-interactional portrayal can be found in Tre commercial (3). The South Asian family portrayed does not interact with other characters in the commercial. In fact, all the families in the commercial practice their cultural tradition at home, with distinct differences in practices, are maintained parallel. The Volvo (2) commercial presents an interesting case where a few East Asians are represented. They are engineers, an integral part of Volvo, sojourners (one of the men makes a phone call to someone before he leaves home to go to work), they speak their own language, and are isolated from the blue-colour setting of the Volvo factory floor. The portrayal corresponds to the model 
minority image in US advertisements (Taylor and Stern 1997; Paek and Shah 2003) and the isolation depicts the 'forever foreigner' status of East Asians (Takaki 2012).

\subsubsection{Tokenism in Swedish Commercials}

Analysing the 23 commercials and the representation of POC, we observe many ethnically ambiguous actors represented. Here, the idea of tokenism becomes interesting and relevant. As Sweden takes a liberal multicultural approach, it can be assumed that marketers employ ethnically ambiguous characters in commercials to 'serve all' instead of targeting specific racial and ethnic groups. This calls attention to how ethnically ambiguous characters in commercials are utilized as representations of diversity in Sweden.

Several commercials utilize ethnically ambiguous 'non-White' celebrities who are, from the beginning, visible in the Swedish media. For example, in the ICA commercial (1), two national football players-Zlatan Ibrahimović and Jimmy Durmaz-represent the 'non-White' main characters. ICA also uses Swedish actors such as Dragonir Mrsic and Johnny Depp look-alike Seba Alón (ICA 3). Volvo (4) also has a commercial utilising Swedish House Mafia where two of the members are ethnically ambiguous and have partially non-Swedish backgrounds. These figures play a significant role as tokens, representing someone who is both 'different enough' and 'similar enough' (Gent 2017). It is an effective way of portraying the racial and ethnic diversity that exists in Sweden, since the viewers recognise them as 'having a non-Swedish background'.

Another interesting case of tokenism can be observed in the advertisement by Tre (4). The commercial stands out among the advertisements analysed in two ways: first, there are no White actors and, second, the advertisement specifically focuses on the war in Syria and the subsequent so-called refugee crisis in Europe. The commercial represents the refugees who arrived in Sweden and the Swedish society that opened their country to them. What is ironic is the non-presence of the White dominant majority society in the commercial and therefore no interaction between the majority society and the POC is presented. The advertisement represents persons of Middle Eastern origin predominantly, while there are some Black actors—including the central figure, Sabina Ddumba, who is a Black Swedish singer. The two central figures become tokens, representing what is 'exceptional' about Sweden. Ddumba becomes a token-a bridge to the Swedish majority society-and Kassis (a refugee) is shown as a potential success story-someone who, despite all the turmoil he has gone through, will be fine in Sweden. This commercial effectively portrays Swedish society as 'righteous, generous, humanitarian' and in pursuit of equity and cultural pluralism (Riegert and Hovden 2019; Hultén 2006).

\section{Concluding Remarks}

This article studies racial and ethnic representation in advertisements, in a context that has become highly diverse and multicultural only within half a decade, by empirically examining how POCs are represented over time. We examined 676 TV commercials aired in Sweden between 2008 and 2017 and quantitatively explored whether POC are represented and what kind of roles they play. Whereas the quantitative analysis focused on the numbers of various combinations of POC representations, the qualitative analysis focused on selected TV commercials and looked more carefully into the quality of the representation, how POCs are represented in the commercials. In the US, research shows that, although people of colour are seen regularly in TV advertisements, they usually appear as secondary characters (Jacobs Henderson and Baldasty 2003). The quantitative analysis of the 676 Swedish TV commercials for this study shows the same tendency - that, while non-White actors are visible in TV commercials and despite an increase in interaction between White and non-White actors over the years, and also an increase in the relative quantity of POC portrayed, POC are often over-represented playing background roles and are portrayed in isolation. The quantitative and qualitative analyses show the over-utilisation of POC as background actors and thus as tokens in order to portray Sweden as multicultural. Moreover, there is no statistically significant increase in the representation of POC in 
Swedish commercials over the years analysed, while the relative number peaks in 2016 . The increased representation of POC in 2016 can be understood as the effect of Swedish multicultural 'catch all' marketing, responding to the increase in refugee immigration in 2015-2016.

As studies in the US show, Black actors were well represented in the commercials representing POC; however, Asians were invisible. What was striking was the prominence of ethnically ambiguous actors. Middle Easterners can fall into this category, since the group is not as racially distinct as Asians or Blacks. The over-representation of ethnically ambiguous actors can be interpreted as the result of Sweden's neoliberalised, liberal, multicultural marketing policy (see Kymlicka 2013), which uses a 'serve all' and 'catch all' technique in advertising, and where ethnic subjects typically are fetishised and commoditised (Ahmed 2011; Veresiu and Giesler 2018). In line with this perspective, together with the practice of casting well-known figures with immigrant backgrounds, ethnically ambiguous actors may serve as mere tokens to represent a multicultural and racially diverse Sweden.

This article answers the calls for more critical examinations of ethnic and racial representation in marketing in general (Weinberger and Crockett 2018) and in racially dynamic European contexts such as Sweden in particular (Ulver et al. 2019). Now that we have a better overview of the representation patterns in Swedish commercials, there are several points that need to be addressed in further studies. One of the most important questions is the intersection of gender and race. The focus of this analysis was solely on POC and single categorical representation but previous studies and some of the results from this study point to the importance of examining multiple, categorical, intersectional representation, especially of gender and age.

Two important aspects requiring further investigation are the consequences of specific racial and ethnic representations and the quality of the representation. For example, the representation of Black-White marriage in several of the commercials qualitatively analysed is an interesting point of discussion. A study in the US shows that the portrayal of Black-White interracial couples in advertising elicits negative attitudes towards the brand (Bhat et al. 2018), while, in another study, media portrayal was associated with more-positive attitudes towards Black-White interracial marriages, indicating advertising as a way to improve attitudes (Lienemann and Stopp 2013). Considering that persons of African background are not preferred as a marriage partner in Sweden (Osanami Törngren 2011; Osanami Torngren 2018), the frequent portrayal of Black-White couples in advertising and its effect should be followed up in a future study.

From the results we present in this article, we would strongly suggest a wider focus on how companies live up to their diversity representation beyond their marketing. A sheer representation in the form of tokenism does not lead to a just and equitable representation. Moreover, it becomes problematic because the inclusion represented in the commercials does not reflect how the organisation (marketing companies and the brand) actually looks (Peñaloza 2018). How is the ethnic and racial diversity represented inside the companies? Moreover, who are on the frontline (e.g., executive management) and who are in the background (e.g., factory floors) in the actual organisations? Perhaps, the background roles are indeed representative of what large, multinational companies are like today (e.g., Volvo, Ikea, Amazon etc.). The philosophical (and political) question, then, is instead how inclusion actually happens and what role marketing and advertising have in this. On tokenism, Gent (2017) writes that 'tokens are powerful [as reifications of dominant norms] not because they are common, but because they are exceptional', and that 'it is difference that allows for exploitation' (2017, p. 220). Thus, all advertising, in its inherent aim to show exceptionalism and to commodify alluring difference, is most probably doomed to produce tokenism, no matter how it is done. Moreover, if we are to believe the insights from this research, a culture of colour-blindness does not constitute a vaccine against tokenism. The point is then not whether advertising produces tokenism but, rather, how problematic it is.

Author Contributions: S.U., together with the post doc researcher Nina Åkestam and four research assistants, collected the data this article is based on. S.O.T. conducted the analysis. S.O.T. and S.U. contributed to the rest of the paper equally. All authors have read and agreed to the published version of the manuscript. 
Funding: This research was funded by the Kamprad Family Foundation.

Acknowledgments: We would like to thank Nina Åkestam for data collection and Jenny Money for the editorial input.

Conflicts of Interest: The authors declare no conflict of interest.

\section{Appendix A}

Table A1. Overview of the Commercials Analysed Qualitatively.

\begin{tabular}{|c|c|c|c|c|}
\hline Commercial Title & Year & Nr Non-Whites & Main Character & Speaking \\
\hline McDonald's 60s_SWE (1) & 2018 & 11 & & \\
\hline McDonald's MANIFEST (2) & 2018 & 8 & & \\
\hline $\begin{array}{l}\text { Volvo Nya Volvo XC40—bilen du kan } \\
\text { abonnera på (1) }\end{array}$ & 2017 & 6 & & \\
\hline Tre 2016_1 (1) & 2016 & 9 & & \\
\hline Tre 2016_2 (2) & 2016 & 8 & 3 & 3 \\
\hline Tre Jul (3) & 2016 & 11 & 3 & 3 \\
\hline $\begin{array}{l}\text { Tre Sabina Ddumba och Naim Kassis från } \\
\text { Syrien (4) }\end{array}$ & 2016 & & 2 & 2 \\
\hline $\begin{array}{l}\text { ICA reklamfilm } 2016 \\
\text { v.23-Soffexperterna (1) }\end{array}$ & 2016 & & 2 & 2 \\
\hline Volvo Made by People (2) & 2016 & 14 & & \\
\hline Volvo Cars-It's Your Journey (3) & 2016 & & 2 & \\
\hline Telia 9 miljoner skäl att satsa miljarder (1) & 2015 & 8 & & \\
\hline ICA reklamfilm 2015 v.33-Tack Turkiet! (2) & 2015 & & 2 & \\
\hline ICA reklamfilm 2015 v.5-Casting (3) & 2015 & & 2 & \\
\hline Coop B-Reel—“Välkommen tillbaka” (1) & 2015 & & 2 & 2 \\
\hline $\begin{array}{c}\text { ICA reklamfilm } 2014 \text { v.35-Ett viktigt } \\
\text { val! (4) }\end{array}$ & 2014 & 10 & & \\
\hline Coop erbjudanden v. 42014 (2) & 2014 & & 2 & 2 \\
\hline $\begin{array}{l}\text { ICA reklamfilm } 2013 \text { v.32-Äntligen dags } \\
\text { att suga på kräftor (5) }\end{array}$ & 2013 & & & 4 \\
\hline Volvo Lune-Leave The World Behind (4) & 2013 & & 2 & \\
\hline IKEA_Armbryt_SkipThisAd & 2012 & & & 3 \\
\hline McDonald's MCX0307 Open Doors helg (3) & 2010 & & 2 & 2 \\
\hline $\begin{array}{c}\text { Telenor älskar rolig } \\
\text { kommunikation-Mexico (1) }\end{array}$ & 2008 & & 2 & \\
\hline Telenor-Kom in och ät! (2) & 2008 & & & 3 \\
\hline Telenor-Gråt och gnäll (3) & 2008 & & & 2 \\
\hline
\end{tabular}

\section{References}

Ahmed, Sara. 2011. Vithetens Hegemoni. Hägersten: Tankekraft Förlag.

Ahmed, Saifuddin, and Jörg Matthes. 2017. Media representation of Muslims and Islam from 2000 to 2015 : A meta-analysis. International Communication Gazette 79: 219-44. [CrossRef]

Åkestam, Nina. 2017. Understanding Advertising Stereotypes. Ph.D. thesis, Stockholm School of Business, Stockholm, Sweden.

Åkestam, Nina. 2018. Caring for her: The influence of presumed influence on female consumers' attitudes towards advertising featuring gender-stereotyped portrayals. International Journal of Advertising 37: 871-92. [CrossRef]

Barnet, Belinda A. 2009. Idiomedia: The rise of personalized, aggregated content. Continuum 23: 93-99. [CrossRef] 
Bhat, Subodh, Susan Myers, and Marla B. Royne. 2018. Interracial Couples in Ads: Do Consumers' Gender and Racial Differences Affect Their Reactions? Journal of Current Issues \& Research in Advertising 39: 160-77.

Borevi, Karin. 2014. Multiculturalism and welfare state integration: Swedish model path dependency. Identities 21: 708-23. [CrossRef]

Brune, Ylva. 1998. Mörk Magi i Vita Medier: Svensk Nyhetsjournalistik om Invandrare, Flyktingar och Rasism. Stockholm: Carlsson.

Brune, Ylva. 2002. 'Invandrare' i mediearkivets typgalleri. In Maktens (o)lika Förklädnader: Kön, Klass E Etnicitet $i$ det Postkoloniala Sverige. Edited by Paulina De los Reyes, Irene Molina and Diana Molinari. Stockholm: Atlas, pp. 150-81.

Brune, Ylva. 2004a. Nyheter Från Gränsen: Tre Studier i Journalistik om “Invandrare", Flyktingar och Rasistiskt Våld. Göteborg: Institutionen för journalistik och masskommunikation, Univ.

Brune, Ylva. 2004b. Nyhetslogik och främlingssyn i mediernas konstruktion av "invandrare". In Kategorisering och Integration-Om Föreställda Identiteter i Politik, Forskning, Media och Vardag. Strömblad. Rapport från Integrationspolitiska maktutredningen. Edited by Anders Westholm, Karen Borevi and Per Strömblad. Stockholm: SOU, pp. 55-97.

Burton, Dawn. 2002. Towards a critical multicultural marketing theory. Marketing Theory 2: 207-36. [CrossRef]

Chin, Christina B., Noriko Milman, Meera E. Deo, Jenny J. Lee, and Nancy Wang Yuen. 2007. Without a trace: Asian Americans and Pacific Islanders in prime-time television. In Contemporary Asian America: A Multidiciplinary Reader. Edited by Min Zhou and James V. Gatewood. New York: New York University Press, pp. 449-68.

Crockett, David. 2008. Marketing blackness: How advertisers use race to sell products. Journal of Consumer Culture 8: 245-68. [CrossRef]

Cui, Geng. 1997. Marketing strategies in a multi-ethnic environment. Journal of Marketing Theory and Practice 5: 122-34. [CrossRef]

Davis, Judy Foster. 2018. Selling whiteness?-A critical review of the literature on marketing and racism. Journal of Marketing Management 34: 134-77. [CrossRef]

Dixon, Travis L., Kristopher R. Weeks, and Marisa A. Smith. 2019. Media Constructions of Culture, Race, and Ethnicity. Oxford Research Encyclopedia of Communication. [CrossRef]

Edström, Maria. 2018. Visibility patterns of gendered ageism in the media buzz: A study of the representation of gender and age over three decades. Feminist Media Studies 18: 77-93. [CrossRef]

Fernández, Christian. 2019. The unbearable lightness of being Swedish? On the ideological thinness of a liberal citizenship regime. Ethnicities 19: 674-92. [CrossRef]

Fowler, Kendra, and Veronica Thomas. 2015. A content analysis of male roles in television advertising: Do traditional roles still hold? Journal of Marketing Communications 21: 356-71. [CrossRef]

Frick, Hanna. 2019. Här är Sveriges största annonsörer. Dagens Media, January 28.

Fujioka, Yuki. 1999. Television portrayals and African-American stereotypes: Examination of television effects when direct contact is lacking. Journalism \& Mass Communication Quarterly 76: 52-75.

Gans, Herbert J. 1979. Symbolic ethnicity: The future of ethnic groups and cultures in America*. Ethnic and Racial Studies 2: 1-20. [CrossRef]

Gent, Whitney. 2017. Tokenism and cultural (mis) recognition in the "Man with the Golden Voice". Howard Journal of Communications 28: 217-33. [CrossRef]

Gokieli, Natia. 2017. "I want us to trade our skins and our experiences": Swedish Whiteness and "Immigrant Literature". Scandinavian Studies 89: 266-86. [CrossRef]

Gopaldas, Ahir, and Anton Siebert. 2018. Women over 40, foreigners of color, and other missing persons in globalizing mediascapes: Understanding marketing images as mirrors of intersectionality. Consumption Markets E Culture 21: 323-46.

Grier, Sonya A., Kevin D. Thomas, and Guillaume D. Johnson. 2019. Re-imagining the marketplace: Addressing race in academic marketing research. Consumption Markets $\mathcal{E}$ Culture 22: 91-100.

Hagerman, Maja. 2007. Det rena landet: Om att Uppfinna den Svenska Nationalmyten. Stockholm: Nordstedts.

Horsti, Karina, and Gunilla Hultén. 2011. Directing diversity: Managing cultural diversity media policies in Finnish and Swedish public service broadcasting. International Journal of Cultural Studies 14: 209-27. [CrossRef]

Hübinette, Tobias. 2017. Ras och Vithet: Svenska Rasrelationer i går och i Dag. Lund: Studentlitteratur. 
Hübinette, Tobias, and Catrin Lundström. 2014. Three phases of hegemonic whiteness: Understanding racial temporalities in Sweden. Social Identities 20: 423-37. [CrossRef]

Hübinette, Tobias, and Lennart E. H. Räterlinck. 2014. Race performativity and melancholic whiteness in contemporary Sweden. Social Identities 20: 501-14. [CrossRef]

Hübinette, Tobias, Helena Hörnfeldt, Fataneh Farahani, and René Léon Rosales. 2012. Om Ras och Vithet $i$ det Samtida Sverige. Tumba: Mångkulturellt Centrum.

Hultén, Gunilla. 2006. Främmande Sidor: Främlingskap och Nationell Gemenskap i Fyra Svenska Dagstidningar efter 1945. Stockholm: Institutionen för Journalistik, Medier och Kommunikation (JMK), Stockholms Universitet, Available online: https://www.diva-portal.org/smash/get/diva2:189274/FULLTEXT01.pdf (accessed on 28 September 2020).

Jackson, Pamela Braboy, Peggy A. Thoits, and Howard F. Taylor. 1995. Composition of the workplace and psychological well-being: The effects of tokenism on America's Black elite. Social Forces 74: 543-57. [CrossRef]

Jacobs Henderson, Jennifer, and Gerald J. Baldasty. 2003. Race, advertising, and prime-time television. Howard Journal of Communication 14: 97-112. [CrossRef]

Johnson, Guillaume D., and Sonya A. Grier. 2011. Targeting without alienating: Multicultural advertising and the subtleties of targeted advertising. International Journal of Advertising 30: 233-58. [CrossRef]

Karlsson, Helena. 2014. Ruben Östlund's Play (2011): Race and segregation in 'good' liberal Sweden. Journal of Scandinavian Cinema 4: 43-60. [CrossRef]

Khosravi, Shahram. 2009. Displaced masculinity: Gender and ethnicity among Iranian men in Sweden. Iranian Studies 42: 591-609. [CrossRef]

Korzenny, Felipe. 2008. Multicultural marketing and the reasons why. Journal of Advertising Research 48: 173-76. [CrossRef]

Kymlicka, Will. 2013. Neoliberal Multiculturalism? In Social Resilience in the Neoliberal Era. Edited by Peter E. Hall and Michèle Lamont. New York: Cambridge University Press, pp. 99-125.

Licsandru, Tana Cristina, and Charles Chi Cui. 2019. Ethnic marketing to the global millennial consumers: Challenges and opportunities. Journal of Business Research 103: 261-74. [CrossRef]

Lienemann, Brianna A., and Heather T. Stopp. 2013. The association between media exposure of interracial relationships and attitudes toward interracial relationships. Journal of Applied Social Psychology 43: E398-E415. [CrossRef]

Lundberg, Patrik. 2011. Ni sliter själen ur mig. Helsinborgs Dagblad. Available online: https://www.hd.se/2011-0912/ni-sliter-sjalen-ur-mig (accessed on 28 September 2020).

Makgosa, Rina. 2012. Ethnic diversity in Britain: A stimulus for multicultural marketing. Marketing Intelligence $\mathcal{E}$ Planning 30: 358-78.

Maree, Tania, and Yolanda Jordaan. 2016. Rainbow Nation, Rainbow Advertising? Racial Diversity of Female Portrayals in South African Television Commercials. Gender E Behaviour 14: 6814-25.

Martinez, Inmaculada J., Juan Miguel Aguado, and Iolanda Tortajada. 2012. Managing the unbalanced: Gendered mobile appropriation, identity boundaries and social role coordination. Feminist Media Studies 12: 506-16. [CrossRef]

Mastro, Dana. 2015. Why the media's role in issues of race and ethnicity should be in the spotlight. Journal of Social Issues 71: 1-16. [CrossRef]

Mastro, Dana. 2017. Race and Ethnicity in US Media Content and Effects. Oxford Research Encyclopedia of Communication. [CrossRef]

Mastro, Dana, and David Stamps. 2018. 18 Race/Ethnicity and Media. Mediated Communication 7: 341.

Mukhtar-Landgren, Dalia. 2008. City Marketing in a Dual City: Discourses of Progress and Problems in post-Industrial Malmö. In Majority Cultures and the Everyday Practices of Ethnic Difference: Whose House Is This? Edited by Bo Petersson and Katharine Tyler. Basingstoke and New York: Palgrave Macmillan, pp. 55-74.

Niemann, Yolanda Flores. 1999. The making of a token: A case study of stereotype threat, stigma, racism, and tokenism in academe. Frontiers: A Journal of Women Studies 20: 111-34. [CrossRef]

Osanami Törngren, Sayaka. 2011. Love Ain't Got No Color?: Attitude toward Interracial Marriage in Sweden. Malmö and Norrköping: IMER/MIM/Malmö Högskola, Migration och Etnicitet/REMESO/Linköpings universitet.

Osanami Torngren, Sayaka. 2018. Playing the safe card or playing the race card? Comparison of attitudes towards interracial marriages with non-white migrants and transnational adoptees in Sweden. Comparative Migration Studies 6: 10-16. [CrossRef] 
Osanami Törngren, Sayaka. 2019. Talking Color-Blind: Justifying and Rationalizing Attitudes Toward Interracial Marriages in Sweden. In Racialization, Racism, and Anti-Racism in the Nordic Countries. Berlin/Heidelberg: Springer, pp. 137-62.

Osanami Törngren, Sayaka. 2020. Challenging the 'Swedish' and 'Immigrant' Dichotomy: How do Multiracial and Multi-ethnic Swedes Identify Themselves? Journal of Intercultural Studies 41: 457-73. [CrossRef]

Osanami Törngren, Sayaka, and Nahikari Irastorza. Forthcoming. Melting pot or salad bowl? An overview of mixed families in Sweden. Journal of Critical Mixed Race Studes.

Paek, Hye Jin, and Hemant Shah. 2003. Racial ideology, model minorities, and the "not-so-silent partner:" Stereotyping of Asian Americans in US magazine advertising. Howard Journal of Communication 14: 225-43. [CrossRef]

Pallas, Hynek. 2011. Vithet i svensk spelfilm 1989-2010. Ph.D. thesis, Stockholm University, Stockholm, Sweden.

Peñaloza, Lisa. 2018. Ethnic marketing practice and research at the intersection of market and social development: A macro study of the past and present, with a look to the future. Journal of Business Research 82: 273-80. [CrossRef]

Persaud, Subriena, Liz Grauerholz, and Amanda Koontz Anthony. 2018. Gendered Representations and Portrayals in Technology Advertisements: Exploring Variations by Age, Race and Ethnicity. Gender Issues 35: 137-52. [CrossRef]

Peruta, Adam, and Jack Powers. 2017. Look who's talking to our kids: Representations of race and gender in TV commercials on Nickelodeon. International Journal of Communication 11: 16.

Precourt, Geoffrey. 2014. What do we know about multicultural marketing? Journal of Advertising Research, 252-53. [CrossRef]

Pripp, Oscar, and Magnus Öhlander. 2008. Fallet Nogger Black: Antirasismens Gränser. Stockholm: Agora.

Punyanunt-Carter, Narissa M. 2008. The perceived realism of African American portrayals on television. The Howard Journal of Communications 19: 241-57. [CrossRef]

Riccucci, Norma M. 2008. Tokenism. In Encyclopedia of Race and Racism. Edited by John Hartwell Moore. Detroit: Macmillan Reference, pp. 132-34.

Riegert, Kristina, and Jan Fredrik Hovden. 2019. Identity, empathy and argument: Immigrants in culture and entertainment journalism in the Scandinavian press. Javnost-The Public 26: 158-76. [CrossRef]

Roth, Wendy D. 2016. The multiple dimensions of race. Ethnic and Racial Studies 39: 1310-38. [CrossRef]

Sahlin, John Alexander. 2011. Slut med nidbild på Kinapuffar. Available online: https://www.svd.se/slut-mednidbild-pa-kinapuffar-889Y (accessed on 28 September 2020).

Scharrer, Erica, and Srividya Ramasubramanian. 2015. Intervening in the media's influence on stereotypes of race and ethnicity: The role of media literacy education. Journal of Social Issues 71: 171-85. [CrossRef]

Schierup, Carl-Ulrik, and Aleksandra Ålund. 2011. The end of Swedish exceptionalism? Citizenship, neoliberalism and the politics of exclusion. Race E Class 53: 45-64.

Schug, Joanna, Nicholas P. Alt, Philip S. Lu, Monika Gosin Gosin, and Jennifer L. Fay. 2017. Gendered race in mass media: Invisibility of Asian men and Black women in popular magazines. Psychology of Popular Media Culture 6: 222. [CrossRef]

Sobol, Kamila, Mark Cleveland, and Michel Laroche. 2018. Globalization, national identity, biculturalism and consumer behavior: A longitudinal study of Dutch consumers. Journal of Business Research 82: 340-53. [CrossRef]

Song, Miri. 2003. Choosing Ethnic Identity. Cambridge: Polity Press Cambridge.

Statistics Sweden. 2018. Antal personer med utländsk eller svensk bakgrund (fin indelning) efter region, ålder och kön. År 2002-2018. Available online: https://www.statistikdatabasen.scb.se/pxweb/sv/ssd/START_BE_ _BE0101_BE0101Q/Ut1SvBakgFin/ (accessed on 28 September 2020).

Takaki, Ronald. 2012. Strangers from a Different Shore: A History of Asian Americans (Updated and Revised). New York: Little, Brown and Company.

Taylor, Charles R., and Barbara B. Stern. 1997. Asian-Americans: Television advertising and the "model minority" stereotype. Journal of Advertising 26: 47-61. [CrossRef]

Tigervall, Carina. 2005. Folkhemsk Film: Med 'Invandraren' i Rollen som den Sympatiske Andre. Umeå: Sociologiska institutionen, Umeå Universitet.

Tigervall, Carina, and Tobias Hübinette. 2010. Japaner, Japaner, Japaner-Östasiater i svensk bild-och senkultur. Fjärde Världen 1: 22-25. 
Tukachinsky, Riva, Dana Mastro, and Moran Yarchi. 2015. Documenting portrayals of race/ethnicity on primetime television over a 20-year span and their association with national-level racial/ethnic attitudes. Journal of Social Issues 71: 17-38. [CrossRef]

Ulver, Sofia, and Christofer Laurell. 2020. Political Ideology in Consumer Resistance: Analyzing Far-Right Opposition to Multicultural Marketing. Journal of Public PolicyE Marketing 39: 477-93.

Ulver, Sofia, Nina Åkestam, Sara Rosengren, and Christofer Laurell. 2019. Mångfalden har inte ökat i den svenska reklamen. Dagens Nyheter, June 6.

Veresiu, Ela, and Markus Giesler. 2018. Beyond acculturation: Multiculturalism and the institutional shaping of an ethnic consumer subject. Journal of Consumer Research 45: 553-70. [CrossRef]

Waters, Mary C. 1990. Ethnic Options: Choosing Identities in America. Berkeley: University of California Press.

Weinberger, Michelle F., and David Crockett. 2018. Critical Reflections on Consumer Identity. In Consumer Culture Theory. Edited by Eric Arnould and Craig J. Thompson. London: SAGE, pp. 62-84.

Zhang, Qin. 2010. Asian Americans beyond the model minority stereotype: The nerdy and the left out. Journal of International and Intercultural Communication 3: 20-37. [CrossRef]

Migrationsverket. 2018. Statistik. Available online: https://www.migrationsverket.se/Om-Migrationsverket/ Statistik.html (accessed on 28 September 2020).

Publisher's Note: MDPI stays neutral with regard to jurisdictional claims in published maps and institutional affiliations.

(C) 2020 by the authors. Licensee MDPI, Basel, Switzerland. This article is an open access article distributed under the terms and conditions of the Creative Commons Attribution (CC BY) license (http://creativecommons.org/licenses/by/4.0/). 